\title{
KOMIK SELENDANG SITI RUGAYAH: SUATU BACAAN HERMENEUTIK KEROHANIAN
}

\section{(Selendang Siti Rugayah: A Spiritual Hermeneutics Reading)}

\author{
JulinaIsmail@Kamal* \\ julina@usm.my
}

Pusat Pengajian Seni, Universiti Sains Malaysia

\author{
Md. Salleh Yaapar \\ mdsalleh@usm.my
}

Pusat Pengajian Ilmu Kemanusiaan, Universiti Sains Malaysia

Published online: 9 June 2020

To Cite: Julina Ismail @ Kamal dan Md. Salleh Yaapar. (2020). Komik Selendang Siti Rugayah: Suatu Bacaan Hermeneutik Kerohanian. Malay Literature, 33(1), 67-82.

\begin{abstract}
Abstrak
Rejabhad, dikenali sebagai Raja Kartun Malaysia. Keistimewaan karyanya memberi peluang kepada pengkaji menganalisis dari sudut reka bentuk lukisan (visual) dan penceritaan (tekstual). Kajian para ilmuwan lepas banyak membincangkan komik Melayu pada lapisan luaran sahaja. Komik Melayu, terutamanya karya Rejabhad, wajar diteliti dengan lebih mendalam untuk mencungkil maksudnya pada lapisan luar dan dalam. Hal ini penting bagi memahami maksud karya sepenuhnya dan memahami jati diri pengarangnya. Kajian ini tertumpu pada karya komik terpilih Rejabhad, iaitu Selendang Siti Rugayah (1997). Metodologi yang digunakan dalam kajian ini bersifat kualitatif yang melibatkan kaedah tafsir atau analisis literal aspek visual dan tekstual untuk mendapatkan maksud luaran karya berkenaan. Seterusnya, bacaan hermeneutik kerohanian, atau kaedah takwil digunakan untuk memperoleh maksud dalaman atau kerohanian karya komik Selendang Siti Rugayah. Hasil kajian ini membolehkan khalayak mendapat kefahaman tentang maksud dalaman karya dan jati diri atau keperibadian pengarang dalam pengkaryaan komiknya.
\end{abstract}


Kajian berdasarkan bacaan hermeneutik kerohanian ini merupakan satu penjelajahan baharu yang mengubah pandangan tentang kearifan dan kreativiti seorang seniman komik Melayu, khususnya Rejabhad, yang dahulunya dihayati dan difahami hanya berasaskan bacaan luaran semata-mata.

Kata kunci: Seni bersekuen, komik, tafsir, hermeneutik kerohanian, maksud dalaman, jati diri

\begin{abstract}
Rejabhad is more popularly known as Malaysia's "king of cartoons". His works stand out because they provide the opportunity for researchers to analyse them from the angles of visual design and text. Scholarly research in the past has tended only to look at the superficial level of comics. However, those of Rejabhad deserve closer analysis to uncover their meaning on both their superficial and deeper levels. This is important in order to completely understand the meaning of these cartoons and the personality of their creator. This study focuses on Rejabhad's Selendang Siti Rugayah [Siti Rugayah's Shawl] (1997). The methodology employed in this research is a qualitative one, involving analysis of the literal aspects of the visual and textual elements to glean the obvious meaning of this work. A spiritual hermeneutics reading or 'takwil method' is applied to obtain the deeper/spiritual meaning of this comic. The findings of this research enable readers to gain a greater understanding about the deeper meanings of the work and the personality of the writer. The spiritual hermeneutic reading is a new way for exploring works and changing opinions concerning the ability and creativity of Malay comic-book writers, especially Rejabhad, whose works were hitherto appreciated and understood solely on a superficial level.
\end{abstract}

Keywords: Sequential art, comics, interpretation, hermeneutics, spiritual hermeneutics, deep meaning, personality

\title{
PENDAHULUAN
}

Komik ialah suatu bentuk seni bersekuen (sequential art) yang merangkumi aspek visual dan tekstual yang digemblengkan secara bersepadu hingga membangkitkan makna yang dihasratkan. Walaupun kelihatan berbeza daripada karya sastera biasa, komik melibatkan teknik "bercerita" dengan unsur naratif persis seperti yang wujud dalam karya sastera konvensional. 
Hari ini seni komik semakin berkembang luas di Malaysia dengan rupa yang berbeza-beza hasil karya pelbagai pengarang baharu dan lama. Antaranya termasuklah karya Rejabhad, atau nama sebenarnya Rejab bin Had (19392002) yang berasal dari Permatang Pauh, Seberang Perai, Pulau Pinang. Keistimewaan Rejabhad, yang digelar Raja Kartun Malaysia, menarik perhatian pengkaji untuk menganalisis karya komiknya dari sudut reka bentuk lukisan (visual) dan penceritaan (tekstual). Umumnya, kajian para ilmuwan lepas banyak membincangkan karya komik Melayu pada lapisan luaran sahaja. Walhal, komik Melayu, terutamanya karya Rejabhad, sewajarnya diteliti dengan lebih mendalam untuk mencungkil maksudnya pada lapisan luar dan dalam. Hal ini penting terutama bagi memahami karya dan jati diri pengarangnya. Dalam konteks tersebut kajian ini tertumpu pada sebuah karya komik terpilih Rejabhad, iaitu Selendang Siti Rugayah (1997). Metodologi yang digunakan dalam kajian ini bersifat kualitatif yang melibatkan kaedah tafsir atau bacaan atau analisis literal aspek visual dan tekstual untuk mendapatkan maksud luaran karya komik berkenaan. Seterusnya, bacaan hermeneutik kerohanian atau kaedah takwil digunakan untuk memperoleh maksud dalaman dan jati diri pengarangnya dalam karya komik Selendang Siti Rugayah.

Seperti gambaran yang diberikan di atas, proses pentakwilan merupakan pentafsiran dan pemahaman makna tersirat dan simbolik sesebuah karya berdasarkan nilai kerohanian. Walaupun penggunaan teks dan visual dalam sesebuah karya komik kelihatan ringkas, tetapi untuk karya yang mempunyai makna dalaman, dimensi dalaman atau kerohanian itu masih dapat dianalisis dan ditonjolkan oleh para pengkaji atau pembaca komik yang peka.

\section{DIMENSI KEROHANIAN}

Kerohanian merupakan dimensi penting dalam kehidupan manusia dan masyarakat yang berpegang pada agama dan adat istiadat serta budaya. Istilah kerohanian merujuk unsur rohani dalam diri manusia dan ciriciri peribadinya. Dimensi kerohanian manusia merangkumi unsur-unsur seperti roh, jiwa, akal, dan nafsu. Dalam Islam hal ini meliputi nilai seperti memelihara rukun dan amalan agama, termasuk syahadah, solat, zakat, puasa dan ibadat haji, taubat, sabar, syukur, tafakur, cinta, kasih dan rindu kepada Allah. Selain itu dimensi kerohanian meliputi akhlak, sikap adil, tolong-menolong, kasih sayang dan nilai murni lain yang dapat membawa keharmonian dan kebahagiaan dalam kehidupan manusia. 
Dari sudut lain, kerohanian merupakan lawan kepada kejasmanian. Jika tingkah laku manusia terkawal atau terbentuk ke arah yang baik, perlakuan ini sebenarnya dikuasai unsur kerohanian. Unsur kerohanian tersebut berjaya menundukkan unsur kejasmanian dan sensual, terutama hawa nafsu, yang juga terdapat dalam diri manusia. Dengan kata yang lain, kerohanian ialah dimensi dalaman yang menjadi inti sari kepada manusia dan pengawal sifat kemanusiaannya. Dalam karya sastera dimensi ini tidak dapat dihayati dengan bacaan luaran atau kaedah tafsir semata-mata. Sebaliknya, karya sastera dapat dihayati dengan bantuan bacaan dalaman, iaitu bacaan hermeneutik kerohanian atau kaedah takwil. Dimensi kerohanian dalam komik Melayu, khususnya oleh Rejabhad, dapat dirungkai melalui bacaan hermeneutik kerohanian. Bacaan ini dapat memperlihatkan suatu kebenaran baharu terhadap tema dan pokok persoalan komik, bersama keperibadian dan jati diri pengarang, yang selama ini dilihat hanya pada lapisan luaran.

Seperti yang digambarkan di atas, dalam agama Islam dimensi kerohanian manusia terbahagi kepada empat, iaitu roh, jiwa (kalbu), akal, dan nafsu (al-Jiasi, 1977). Dimensi kerohanian merupakan entiti abstrak yang membezakan manusia daripada makhluk yang lain. Menurut alGhazali, roh berasal daripada alam ketuhanan, iaitu alam malakut. Secara fitrah, roh itu suci. Jiwa atau kalbu pula ialah semangat atau perasaan batin yang menunjangi hidup manusia. Seterusnya, akal terlibat dalam proses persepsi, pemahaman rasional dan pembinaan kebanyakan bidang ilmu. Nafsu pula mengurus dan mentadbir tubuh, membekalkan daya pendorong; namun nafsu juga pembekal daya penggerak syahwat dan sifat amarah. Secara keseluruhannya dimensi kerohanian ialah tonggak kehidupan yang membimbing insan sebagai makhluk Allah yang mulia. Dimensi kerohanian tidak kelihatan pada pandangan mata kasar, namun dapat dilihat oleh mata hati lantas difahami manifestasinya. Pendeknya, dimensi kerohanianlah yang memberikan makna kepada diri insan dan kehidupannya. Tanpanya, tujuan hidup dan sebab musabab bagi kejadian insan akan terbang menerawang dan hilang. Hal ini kerana dimensi kerohanian merangkumi aspek seperti ketakwaan kepada Tuhan, kepercayaan kepada agama, penghayatan nilainilai murni dalam masyarakat serta amalan budi pekerti yang mulia.

\section{HERMENEUTIK KEROHANIAN}

Secara amnya, hermeneutik merupakan kaedah pemahaman teks yang digunakan untuk memahami kitab agama, karya sastera, buku umum dan 
pelbagai tulisan lain. Pada asasnya hermeneutik terbahagi kepada dua, iaitu hermeneutik biasa dan hermeneutik kerohanian. Hermeneutik biasa sama maknanya dengan kaedah tafsir. Hermeneutik kerohanian pula merujuk kepada kaedah takwil yang sering digunakan untuk memahami karya yang diyakini mempunyai lebih daripada satu lapisan makna. Hermeneutik kerohanian dapat digunakan untuk memahami karya masa lalu, mahupun masa kini. Yang penting, hermeneutik kerohanian bertitik tolak pada kepercayaan tentang wujudnya makna lapisan dalaman atau simbolik dalam sesebuah karya.

Jika dihayati dan difahami dengan teliti, hermeneutik ini dapat membawa si pembaca atau si pengkaji kepada makna kerohanian yang tersembunyi di sebalik teks atau visual luaran yang terdapat di permukaan karya. Menurut Md. Salleh Yaapar dalam bukunya Pilgrimage to the Orient (2009, pp. 72-77) pada asasnya hermeneutik meyakini bahawa makna komunikasi manusiawi boleh difahami melalui dua jenis pentafsiran yang sewajarnya saling lengkap-melengkapi. Pertama, tafsir yang digunakan oleh pentafsir luaran (exoteric exegete) yang memberikan perhatian pada permukaan teks. Kedua ialah takwil, iaitu tafsiran simbolik yang dilaksanakan oleh pentafsir dalaman (esoteric exegete), khususnya terhadap karya yang mempunyai unsur-unsur kerohanian. Tafsiran jenis kedua itu melangkaui bentuk luaran dan lebih mengarah kepada realiti dalaman teks yang dihayati. Dalam tulisan awalnya, "A Pilgramage to the Orient: Ta'wil as a form of Islamic Hermeneutics"(1988, pp. 44-49), Md. Salleh menegaskan bahawa dalam tradisi Islam, kaedah atau proses tafsir, iaitu pentafsiran literal, hanya membawa kepada pemahaman luaran terhadap sesebuah teks yang dikaji. Sebaliknya, kaedah atau proses takwil, yang sering dilakukan oleh ahli sufi, dapat membawa kepada pemahaman kerohanian, iaitu pemahaman yang lebih menyeluruh dan mendalam.

Menurut Abdul Hadi W. M. (2014, p. 151) dalam tulisannya mengenai perkembangan takwil, hermeneutik kerohanian Islam bermula pada abad ke-10 dan ke-11. Pelopornya terdiri daripada para ulama Sufi seperti Sulami, Sahl al-Tustari, Mansur al-Hallaj, Qusyairi dan al-Ghazali. Sejak abad ke-16, para penulis sufi di Nusantara pula, seperti Syamsudin al-Sumatrani, Hamzah Fansuri dan Sunan Bonang, mula menerokai hermeneutik kerohanian Islam ini. Pada akhir 1970-an hermeneutik kerohanian diperkenalkan semula dan digunakan, antaranya termasuklah Abdul Hadi yang mengkaji karya para penulis Melayu-Islam Nusantara. 
Abdul Hadi (2014, p. 154) juga mengulas tentang takwil yang dikatakan pernah digunakan sebagai pendekatan dalam penelitian karya para penulis Melayu-Islam klasik. Hal ini kerana estetika sastera Melayu klasik sesuai dengan beberapa landasan takwil. Pertamanya, kebanyakan karya penulis Melayu klasik mempunyai hubungan rapat dengan ilmu dan amalan tasawuf yang mencakupi pandangan dunia atau pandangan hidup yang bersifat kerohanian. Hal ini dapat dilihat menerusi konsep idea dan estetika karya sastera yang umumnya dianggap sebagai ungkapan simbolik daripada pengalaman rohaniah seseorang pengarang. Oleh itu, secara tidak langsung, seni sastera Melayu klasik, secara tersirat atau tersurat, mempunyai hubung kait dengan pemikiran metafizikal Sufi yang merangkumi aspek ontologi, kosmologi, psikologi, epistemologi dan etika.

Seterusnya, menurut Abdul Hadi lagi, takwil dapat dilaksanakan sekiranya seseorang pengkaji atau sarjana mampu menggabungkan cakerawala pemikirannya dengan cakerawala teks yang dikajinya. Dengan cara ini dapat menyingkap makna dalaman teks yang luas berbanding makna luarannya yang sering terbatas. Dalam konteks inilah takwil dapat dikaitkan dengan al-fahm (kefahaman) tentang pengalaman atau kisah yang diungkapkan secara simbolik dalam teks. Ahli Sufi mempraktikkan kaedah takwil berdasarkan penghayatan pengalaman kerohanian dalam penyatuan diri dengan teks menerusi kesedaran dan imaginasi secara kreatif. Seterusnya, pemahamannya juga diperkaya oleh pengetahuannya tentang latar kebudayaan dan latar peribadi pengarang.

\section{SELENDANG SITI RUGAYAH: SUATU KISAH PERCINTAAN}

\section{Simbolik}

Tafsiran dan pemahaman terhadap karya komik Rejabhad, Selendang Siti Rugayah, umumnya dilakukan hanya pada lapisan luaran. Karya ini sekadar kisah percintaan sepasang kekasih yang tidak kesampaian. Malah, komik ini difahami hanya sebagai sebuah karya yang berbentuk jenaka atau lucu. Walau bagaimanapun daripada penelitian didapati karya ini mengandungi pengertian yang jauh lebih mendalam. Kajian ini akan menganalisis Selendang Siti Rugayah dengan menggunakan bacaan hermeneutik kerohanian atau kaedah takwil. Analisis ini pastinya akan mengambil kira nilai budaya Melayu tradisional, dari perspektif dan amalan hidup masyarakat Islam yang menjadi latar belakang pengarang, iaitu Rejabhad. 
Bacaan pada peringkat permukaan atau luaran, komik Selendang Siti Rugayah menampilkan kisah percintaan yang tidak kesampaian antara dua insan. Bacaan yang lebih mendalam memperlihatkan senario kisah cinta yang lebih tinggi dan mulia, iaitu kisah pasang surut hubungan cinta antara jiwa insan dengan Tuhan yang menciptanya. Dalam konteks ini Selendang Siti Rugayah ialah karya komik yang simbolik, sarat dengan peringkat-peringkat hubungan mistik yang melibatkan pencarian rohani dan persoalan ontologi atau keperihalan wujud. Pada asasnya, seperti kebanyakan karya mistikal, karya simbolik ini menampilkan jiwa insan dalam pencarian rohani yang melibatkan keadaan naik turun dan liku-liku percintaan antara manusia dengan Tuhannya.

\section{Cinta dan Sumpah Setia}

Pengarang memulakan komik Selendang Siti Rugayah menggambarkan pasangan muda, Leman dan Gayah, berdua-duaan di dalam hutan. Di tempat yang jauh daripada masyarakat kampung itu Leman melorekkan pada sebatang pokok namanya bersama nama Gayah sebagai simbol cinta sejati mereka. Gambaran ini memperlihatkan suatu perjanjian ikatan percintaan antara Leman dan Gayah. Dalam suasana romantik itu dialog cinta mereka terserlah seperti berikut (Rejabhad, 1977, p. 1):

Leman: Tengok Gayah, abang lorekkan cinta kita, selagi hutan ini tidak dipugar, selagi itu cinta kita berbunga.

Gayah: Dan menguatkan lagi bukti bagi pencegah maksiat bila kita ditangkap basah.

Percintaan antara mereka berdua memang kental dan mendalam. Seperti yang akan diceritakan lagi oleh pengarang, mereka sering berjumpa secara berdua-duaan di tempat yang sunyi, dan melakukan dosa di sana termasuklah berpegang tangan, tepuk-menepuk, peluk-memeluk dan gosok-menggosok badan. Semua ini mereka lakukan, iaitu perbuatan yang melanggar adat Melayu dan hukum agama Islam. Leman dan Gayah sebenarnya diruntun hawa nafsu sehingga lupa terhadap kewajipan manusia untuk sentiasa mencintai Allah SWT, dan mematuhi suruhan dan larangan-Nya.

Gambaran visual bersama-sama teks perjanjian cinta di atas menampakkan wajah gembira seorang pemuda dan kekasihnya, yang asyik dalam percintaan sehingga lupa kepada Allah yang menciptakan mereka. 
Akan tetapi, jika dilihat menerusi proses pentakwilan oleh seorang pembaca yang peka pada agama Islam dan arif dari sudut kerohanian, gambaran visual di bawah pokok ini menimbulkan makna yang lebih mendalam. Pokok yang digambarkan oleh pengarang segera mengingatkan pembaca pada suatu kisah pokok dalam al-Quran. Perihal pokok yang terakam sebagai simbol dalam kitab suci tersebut, khususnya dalam Surah Ibrahim, adalah seperti berikut:

Tidakkah kamu perhatikan bagaimana Allah telah membuat perumpamaan kalimat yang baik seperti pohon yang baik, akarnya teguh dan cabangnya (menjulang) ke langit. Pohon memberikan buahnya pada setiap musim dengan seizin Tuhannya. Allah membuat perumpamaan-perumpamaan ini untuk manusia supaya mereka selalu ingat. Dan perumpamaan kalimat yang buruk seperti pohon yang buruk, telah dicabut dengan akar-akarnya dari permukaan bumi; tidak dapat (tegak) sedikitpun. Allah meneguhkan (iman) orang-orang yang beriman dengan ucapan yang teguh itu dalam kehidupan di dunia dan di akhirat; dan Allah menyesatkan orang-orang zalim dan memperbuat apa yang Dia kehendaki.

(Surah Ibrahim 14: 24-27)

Dalam konteks surah ini gambaran visual, dengan lakaran tekstual sumpah cinta pada pokok di atas, segera memperingatkan pembaca terhadap kelemahan iman dan kealpaan pasangan tersebut terhadap hubungan jiwa mereka dengan Tuhan. Mereka asyik bercinta sesama manusia dan melakukan dosa dengan berkhalwat atau berdua-duaan di dalam hutan. Semua ini dilakukan tanpa sedikitpun rasa takut kepada Sang Pencipta, jauh sekali rasa cinta terhadap-Nya.

Dalam perkembangan cerita seterusnya pengarang memperlihatkan lagi suasana romantis dan kekentalan rasa cinta pasangan tersebut. Sekali lagi, mengetepikan norma dan adat istiadat Melayu serta hukum hakam agama Islam, pasangan tersebut masuk ke hutan untuk bercengkerama. Di sana Gayah menampilkan sehelai selendang sebagai tanda pengukuhan ikatan percintaan mereka. Selendang yang dibahagi dua itu dicipta oleh Gayah sendiri dan diharumkan dengan wangian "Sedap Malam". Ia dibawa ke tempat khalwat mereka dan ditonjolkan oleh Gayah sebagai simbol ikatan perjanjian bahawa cinta mereka tidak akan luntur. Malah, mereka akan sentiasa bersama selama-lamanya. Gayah yakin hanya maut yang boleh memisahkan mereka berdua. Kagum melihat selendang yang cantik dan mendengar kata-kata setia Gayah, Leman lantas bertanya. Dialog romantik 
mereka tentang selendang simbolik ini adalah seperti yang berikut (Rejabhad, 1977, p. 4):

Leman: Tapi, bagaimana kalau Gayah atau abang berkahwin
dengan orang lain?

Gayah: Kita cari jalan untuk berpisah, walaupun sudah beranak empat.

Leman: Kalau beranak empat masih belum berpisah, bagaimana? Gayah: Sehingga pasangan kita mati.

Jika ditafsirkan secara luaran gambaran di atas tidaklah mengejutkan. Gambaran biasa tentang pasangan yang taat dan taksub dalam bercinta. hatta sanggup memecahkan keluarga yang sudah beranak empat. Namun begitu, apabila dilakukan bacaan hermeneutik kerohanian hasilnya lebih daripada itu. Yang ketara di sini ialah hakikat bahawa Gayah dan Leman telah sama-sama lupa pada hukum agama. Malah, mereka juga lupa pada takdir dan kuasa Tuhan serta hikmah di sebalik sesuatu kejadian. Mereka berdua sedang ghairah bercinta sesama manusia, tetapi pada masa yang sama sedang mengalami kerapuhan iman dan ketipisan cinta terhadap Allah SWT.

Ucapan Leman dan Gayah dalam kedua-dua peristiwa di atas menggambarkan sifat hamba yang lupa akan Tuhan-Nya. Hal ini kerana mereka taksub dengan cinta dan sumpah setia antara sesama manusia sehingga berpegang hanya pada tanda atau simbol cinta pada sebatang pokok dan sehelai selendang, dan melupakan kuasa, perintah dan takdir Allah. Dalam tradisi Islam beriman kepada Allah SWT bererti mengakui adanya Allah Yang Maha Pencipta bersama kuasa, perintah dan takdirNya. Pada dasarnya, iman kepada Allah bagi manusia telah sedia wujud ketika manusia itu dilahirkan. Oleh itu, manusia wajib menurut perintah Allah, di samping memerlukan perlindungan secara mutlak dan menerima takdir-Nya. Kecenderungan mencari perlindungan ini disebut sebagai naluri agama (religious instinct). Jika agama dipegang kuat, maka kuatlah naluri agama dan iman seseorang itu. Perbuatan Leman dan Gayah seperti di atas mengukuhkan cinta sesama mereka. Pada masa yang sama memperlihatkan kelalaian dan kerosakan iman mereka terhadap Allah SWT. Ertinya, hubungan cinta yang sedia ada antara mereka dengan Tuhan telah ternoda atau sudah diputuskan, sehingga mereka lupa pada perbuatan dosa dan takdir serta hikmah sesuatu kejadian. Mesej dalaman inilah yang ingin disampaikan oleh pengarang Selendang Siti Rugayah. 


\section{Cinta dan Dugaan}

Dalam perkembangan seterusnya pengarang Selendang Siti Rugayah menampilkan kisah percintaan Leman dan Gayah diuji apabila Gayah tiba-tiba dipaksa berkahwin dengan pilihan ibu bapanya, iaitu Tuk Bek, seorang tok guru silat yang terkenal di kampung mereka. Idea kahwin paksa ini menimbulkan konflik antara Gayah dengan ibu bapanya. Hal ini tidak sahaja kerana Tuk Bek bukan orang yang dicintainya, malah kerana Tuk Bek sudah tua. Jelas di sini kekuatan cinta Gayah terhadap Leman juga diuji oleh pilihan kedua-dua ibu bapanya yang telah bersetuju menerima tepak sirih pinangan Tuk Bek. Secara zahirnya di sini pengarang menampilkan visual dan teks yang menggerunkan, iaitu tentang Gayah terpaksa memilih antara keris pusaka (ertinya Gayah perlu bunuh diri) dengan beg pakaian (Gayah perlu tinggalkan rumah dan ibu bapa). Gayah diperlihatkan mengalami pergolakan jiwa apabila perasaannya mula berasa serba-salah dan ketakutan untuk membuat keputusan. Hal ini diungkapkan menerusi ujarannya seperti berikut (Rejabhad, 1977, p. 13):

Gayah: Kalau saya pilih beg pakaian saya akan jadi layang-layang putus tali...

Kalau saya pilih keris, saya akan mati sesat, sedangkan lima kali sehari memohon kepada Tuhan agar sentiasa di jalan yang lurus lagi diredhai.

Gayah: Saya terpaksa pilih tepak sirih walaupun saya tidak suka memakannya.

Menurut bacaan luaran ujaran di atas memperlihatkan bahawa Gayah tidak memilih beg pakaian kerana dia tidak biasa hidup sendirian. Dia juga tidak memilih keris, yakni membunuh diri, kerana itu bertentangan dengan amalan solat dan doanya seharian, ada sekelumit iman dalam diri untuk tidak mati dalam keadaan sesat. Oleh itu, dia menerima tepak sirih, yakni menerima lamaran Tuk Bek, walaupun orang itu tidak disukainya. Dalam hal ini bacaan hermeneutik kerohanian akan menambah satu lagi perkara, iaitu Gayah menerima lamaran Tuk Bek kerana perkara itu telah ditakdirkan Allah untuknya. Keadaan ini memperlihatkan bahawa ikatan jiwanya dengan Tuhannya masih teguh. Hakikatnya ujian yang diturunkan oleh Allah SWT terhadap Gayah, dan keluh kesah bisikan hatinya, memberikan kesan positif, iaitu untuk menjadikannya lebih dekat dengan Yang Maha Berkuasa. Hal ini bersesuaian pula dengan firman Allah dalam al-Quran, seperti yang berikut: 
Dan Sesungguhnya Kami telah menciptakan manusia dan mengetahui apa yang dibisikkan oleh hatinya, dan Kami lebih dekat kepadanya dari urat lehernya.

Begitulah, Gayah telah menerima takdir yang ditentukan Allah untuknya, dan jiwanya kembali memelihara hubungan yang rapat dengan Tuhannya. Namun begitu, tidaklah mudah pula untuknya memaklumkan kepada kekasihnya Leman keputusannya menerima pinangan Tuk Bek. Apabila keputusan itu disampaikan maka Leman segera bertanya bagaimana kedudukan perjanjian cinta kasih mereka berdua. Gayah menjawab secara mudah, iaitu "Perjanjian dengan Tuhan orang batalkan, inikan pula sesama manusia." Jawapan ini amat mengejutkan Leman.

Seterusnya, terperanjat dan kecewa dengan jawapan Gayah, Leman segera pulang ke rumah dan memberitahu kawannya Malim berita sedih hasil perjumpaan antara dia dengan kedua-dua ibu bapa Gayah serta dengan Gayah. Malim telah memujuk Leman yang ketika itu sedang menangis di hadapannya dengan berkata (Rejabhad, 1977, p. 20):

"Jangan menangis, Leman. Lelaki pantang menangis, lelaki hanya boleh menangis ketika sembahyang Tahajud dan di hadapan Ka'abah saja).

Mendengar kata-kata Malim, yang diselit dengan cabaran kelelakian dan nasihat keagamaan, resah gelisah Leman mulai reda. Hatinya juga mula berpaling kembali kepada Allah SWT dan semakin banyak mengingati-Nya.

\section{Cinta Sesama Manusia dan Cinta kepada Yang Maha Esa}

Dalam perkembangan seterusnya, Leman ditakdirkan menerima tamparan lagi. Temannya Malim, yang sebenarnya juga cintakan Gayah, telah berjaya mendapatkan persetujuan Tuk Bek untuk melepaskan gadis tunangannya itu. Malim sebenarnya telah menggunakan minyak pengasih, dan dengan minyak itu Gayah telah tiba-tiba berubah menjadi gadis yang tergila-gila kepadanya. Melihat keadaan Gayah yang demikian Tuk Bek segera menyerahkan gadis itu kepada Malim. Keadaan ini menjadikan Leman terus patah hati, tetapi terpaksa menerimanya. Dalam keadaan tersebut Leman telah membuat keputusan untuk membawa diri keluar dari rumah dan kampungnya. Dia pergi dengan perasaan hati yang luka dan sedih seperti yang dapat difahami 
pada keluhannya ini: “Aku hampa, Gayah! Aku kecewa!! Hidup aku punah, Gayah!! (Rejabhad, 1977, p. 46). Pak Sukun, seorang bomoh yang mendengar keluhan Leman, segera menegurnya dengan memberi nasihat keagamaan. Teguran itu menimbulkan dialog antara mereka berdua, seperti yang berikut (Rejabhad, 1977, p. 47):

Leman: Biarkanlah saya seorang diri di sini.

Pak Sukun: Sebenarnya awak berteman.

Leman: Siapa teman saya?

Pak Sukun: Syaitan. Syaitan memang suka orang yang mengeluh seorang diri, kecuali orang yang sedang bertafakur.

Walaupun pahit, teguran itu ditelannya, malah telah berjaya pula meredakan perasaan kecewa Leman. Akhirnya dia pasrah dan kembali menyerah kepada takdir Allah.

Seterusnya, pengarang mengakhiri konflik cerita dalam Selendang Siti Rugayah dengan menyatukan Malim dan Gayah sebagai suami isteri yang sah. Leman yang mengetahui perkembangan ini lagi sekali redha dengan ketentuan Tuhan dan bertekad untuk merapatkan semula dirinya dengan Allah SWT. Dia bermadah kepada Gayah dengan serangkai kata-kata (Rejabhad, 1977, p. 56):

Aku akan mengembara hingga ke Makkah, di sana aku akan abdikan diri aku kepada Allah di kaki Kaabah, kerana aku tau dan aku sedar, hanya cinta kepada Allah sahaja satu-satunya cinta yang sejati, murni dan dapat memberikan kebahagiaan kepada kita di dunia dan di akhirat.

Malah, Leman sempat pula menenangkan hati sanubari bekas kekasihnya yang sedang menangis di hadapan suaminya Malim (Rejabhad, 1977, p. 56):

"Gayah! Kita gagal mencantum Selendang Siti Rugayah di malam pertama seperti yang kita rancangkan di dunia..."

"Tak apa Gayah... kita akan cantumkannya di akhirat kelak."

Dengan madah yang indah lagi positif itu Leman pun mengucapkan selamat tinggal kepada pasangan Gayah dan Malim, yang kini digelarnya Juliet dan Antonio, lantas berlalu pergi. 
Seterusnya, walaupun dalam apa-apa situasi Leman sudah bertekad untuk mengabdikan diri kepada Allah di kaki Kaabah, Leman masih berdepan dengan dugaan cinta manusiawi. Kali ini ia didatangi dan digoda pula oleh Bibah, seorang lagi gadis di kampungnya. Namun begitu, Leman tetap tabah dan cintanya kepada Allah masih tidak goyah. Dengan mudah ia membalas rayuan si Bibah, seperti berikut (Rejabhad, 1977, p. 58):

Aku dalam perjalanan ke Kaabah, janganlah kau halang perjalanan aku dengan sebuah pelamin.

Begitulah halnya jiwa yang sudah merasai nikmat cinta Ilahi akan lebih sensitif terhadap gangguan yang menghalang perjalanannya kembali kepada Yang Maha Esa. Jiwa itu juga dapat dengan mudah melupakan cinta manusiawi, malah dapat pula memahaminya dalam konteks alam abadi.

Jelaslah dalam beberapa petikan teks dan visual di atas Leman, watak protagonis dalam Selendang Siti Rugayah, telah menemui cinta sejati, iaitu cinta terhadap Ilahi. Ia juga redha dengan ujian terhadap diri dan pasangannya di dunia yang fana. Situasi ini merupakan gambaran keyakinan watak manusia terhadap takdir dan cinta kepada Allah SWT. Sekiranya jiwa manusia lalai dan hilang cinta terhadap Tuhan, perlu diisi segera kekosongan hati dan jiwa itu dengan mendekatkan kembali diri kepada-Nya. Dalam konteks inilah Leman, yang redha dengan ketentuan Allah dan sedang membawa dirinya ke luar kampung, telah berhenti di sebatang sungai, membuang selendang Siti Rugayah, lantas berkata (Rejabhad, 1977, p. 57):

Wahai kaki, bawalah aku ke Makkah.

Wahai sungai, kau telanlah Selendang Siti Rugayah ini agar ianya tidak lagi dalam ingatan aku.

Dengan ini jelaslah bahawa cinta kepada Allah SWT akan berkembang mekar jika seseorang itu sentiasa berusaha mengisi kekosongan jiwa dan menguatkan imannya, serta sentiasa dalam pencarian rahsia batinnya (sirr) sambil berjalan menuju Tuhan. Kekuatan jiwa dan iman menjadikan seseorang manusia itu lebih bahagia dan sejahtera. Sesungguhnya, cinta yang tulen dan abadi ialah cinta kepada Allah SWT. Inilah hasil pencarian makna rohani melalui takwil terhadap teks dan visual dalam Selendang Siti Rugayah. 


\section{JATI DIRI REJABHAD}

Kajian dalaman, melalui hermeneutik kerohanian, terhadap karya Selendang Siti Rugayah dapat memperlihatkan unsur jati diri dan keperibadian pengarang komiknya, iaitu Rejabhad. Jati diri atau identiti pengarang merupakan faktor utama yang memberi kekuatan dan citra kepada sesebuah karya, dengan karya itu melambangkan pula keperibadian pengarangnya. Jati diri Rejabhad pernah diperkatakan dengan merujuk kepada objektif yang menjadi pegangan beliau dalam berkarya, iaitu "Menghibur, Mengajar dan Menyedarkan" (3M). Bagi beliau dalam berkarya setiap seniman semestinya mempunyai rangkaian objektif untuk "Menghibur, Mengajar dan Menyedarkan". Tinjauan sepintas lalu terhadap korpus karya beliau, termasuk antaranya Tan Tin Tun (1987), Perwira Mat Gila (1988) dan Mawar oh Mawar (2001), memberi gambaran bahawa beliau berpegang kepada rangkaian objektif tersebut, malah merupakan unsur keperibadian dan jati diri beliau sebagai pengarang. Keperibadian ini pula mencerminkan Rejabhad sebagai seorang pengarang yang kuat mendukung budaya Melayu dan taat kepada beragama Islam. Sebagai pengarang Melayu yang berpegang teguh kepada agamanya, beliau menerapkan unsur keislaman dan unsur budaya Melayu dalam karyanya. Semua ini dapat dirungkaikan oleh pengkaji menerusi bacaan dalaman, yakni hermeneutik kerohanian.

Seperti yang dibayangkan di atas, antara sifat jati diri Rejabhad ialah keperibadiannya sebagai seorang pengarang yang yakin terhadap agama Islam. Beliau berinteraksi berdasarkan jiwa, fikiran, hati dan akal yang menjurus kepada jati dirinya sebagai hamba Allah SWT. Keperibadiannya ditonjolkan menerusi karyanya yang mencerminkan akhlak manusia dalam masyarakat yang berpegang pada ajaran agama Islam. Akhlak yang tercermin daripada setiap perbuatan manusia itu membezakan jiwa seseorang manusia daripada manusia yang lain. Dalam tradisi Islam dalam jiwa manusia biasanya dibahagikan kepada tiga peringkat nafsu (al-Jiasi, 1977, p. 27). Pertama ialah peringkat nafsu muthmainnah, iaitu jiwa yang mendapat cahaya keimanan dan berada dalam keadaan tenang. Kedua ialah peringkat nafsu lawwamah, iaitu jiwa yang mengenal baik dan buruk. Pada tahap ini ada kalanya manusia melakukan kebaikan, dan ada kalanya manusia melakukan kejahatan. Yang terakhir peringkat nafsu ammarah, iaitu jiwa yang jahat dan mengarah kepada kejahatan.

Dalam komik Selendang Siti Rugayah, Rejabhad menampilkan secara luaran dan jelas kisah gejolak cinta antara Leman dengan Gayah. Kemabukan cinta ini menyebabkan kedua-dua watak lupa kepada hubungan azali mereka 
dengan Allah SWT. Malah, kealpaan mereka terhadap Allah SWT sering menyebabkan mereka menurut hawa nafsu, lantas melanggar perintah-Nya dengan berkhalwat dan melakukan maksiat. Jika dibaca secara tafsir biasa memang kisah ini hanyalah kisah cinta sesama manusia. Namun begitu, menerusi bacaan takwil, di sebalik kisah cinta itu terselit kisah keingkaran dan keinsafan manusia dalam hubungannya dengan Tuhannya. Subjek inilah yang ditonjolkan Rejabhad sebagai pengarang Selendang Siti Rugayah. Karyanya menampilkan manifestasi jati diri Rejabhad sebagai pengarang yang menitikberatkan iman dan cinta kasih kepada Allah dan amalan budaya murni dalam masyarakat Melayu yang beragama Islam. Hal ini sesuai dengan kata-kata beliau seperti yang dipetik dalam Majalah Humor Nasional GilaGila (13 April 2008), iaitu "Kartunis tempatan seharusnya mempromosikan budaya sendiri daripada mempromosikan gaya dan budaya asing".

\section{KESIMPULAN}

Perbincangan di atas, yang berasaskan hemeneutik kerohanian, menunjukkan bahawa buku komik Selendang Siti Rugayah oleh Rejabhad bukan sekadar menampilkan kisah cinta antara lelaki dengan perempuan, yakni cinta sesama manusia. Hal ini kerana di sebalik kisah tersebut wujud realiti yang agak tersembunyi, iaitu kisah naik turun iman manusia dan kelenturan cinta jiwanya terhadap Sang Pencipta. Pada lapisan atasnya Selendang Siti Rugayah rakaman kisah pasangan remaja yang bernama Leman dan Gayah yang mengharungi alam percintaan yang menghadapi satu demi satu dugaan. Pertama, Gayah dipaksa oleh ibu bapanya untuk berkahwin dengan Tuk Bek, seorang guru silat yang sudah tua. Hal ini bukan sahaja sukar diterima oleh Gayah, tetapi juga menjadikan Leman begitu kecewa. Seterusnya, dengan menggunakan minyak pengasih Malim, rakan karib Leman, telah berjaya merampas Gayah daripada Tuk Bek. Hal ini lagi sekali amat melukakan hati Leman. Namun begitu, pada masa yang sama, pada lapisan yang dalam terselit kisah pergelutan Leman merealisasikan iman dan cinta kasih terhadap Tuhannya. Leman, yang dahulunya asyik bercinta tanpa mengambil kira suruhan dan tegahan Allah SWT, kini telah mulai ingat dan kembali pada Tuhan dan redha dengan ketentuan-Nya. Malah, ia sudah bertekad untuk merapatkan semula dirinya dengan Allah SWT. Untuk itu Leman memasang niat untuk naik haji ke Makkah dan mengadap Allah di Kaabah.

Begitulah, Selendang Siti Rugayah oleh Rejabhad sebenarnya bukan sekadar cerita komik yang berunsur jenaka. Sebaliknya merupakan sebuah 


\section{MALAY LITERATURE VOLUME 33 NUMBER 1 JUNE 2020}

cerita yang berkait dengan perjuangan jiwa manusia untuk kembali dekat dengan Tuhannya. Dalam karya Rejabhad ini terselit sebuah kisah pencarian rohani yang berliku dan sukar untuk direalisasikan kerana faktor nafsu dan tarikan kuat cinta manusiawi. Kisah ini bersifat simbolik pasang surut hubungan cinta antara jiwa insan dengan Tuhan yang menciptakannya. Karya dengan makna yang berlapis ini merupakan suatu pencapaian tinggi pengarang komik Melayu Rejabhad. Pengarang berjaya mencapai kejayaan ini kerana beliau mempunyai jati diri yang kental sebagai seorang aktivis dan tokoh seni komik Melayu Islam.

\section{RUJUKAN}

Abdul Hadi, W. M. (2014). Hermeneutika Sastra Barat dan Timur. Jakarta: Sadra Press.

Al-Jiasi, Mustapha Mohamed. (1977). Mengenal Diri dan Wali Allah. Kota Bharu: Pustaka Aman Press Sdn. Bhd.

Muhammad Noor Haji Ibrahim, Abdullah Basmeh. (2010). Tafsir Pimpinan arRahman kepada Pengertian al-Qur'an (30 juzuk). Kuala Lumpur: Darul Fikir.

Md. Salleh Yaapar. (2009). Pilgrimage to the Orient. Kuala Lumpur: Institut Terjemahan Negara Malaysia.

Md. Salleh Yaapar. (1988). A Pilgramage to the Orient: Ta'wil as a Form of Islamic Hermeneutics. Muslim Education Quarterly (Cambridge), 5(3) (Spring), 44-49.

Rabena. (2008). Rejabhad Raja Kartun Malaysia yang Sukar dicari Ganti. Majalah Humor Nasional Gila-Gila. Akses pada 3 April 2019, daripada http://jiwatempatan.blogspot.com/2008/04/allahyarham-rejabhad-rajakartun.html

Rejabhad. (2008). Akses pada 23 April 2013, daripada http://darialmarikartun. blogspot.com/2008/01/rejabhad.html

Rejabhad. (1997). Selendang Siti Rugayah. Siri Produksi Gila-Gila. Kuala Lumpur: Creative Enterprise Sdn. Bhd.

Rejabhad. (2001). Mawar oh Mawar. Siri Produksi Gila-Gila. Kuala Lumpur: Creative Enterprise Sdn. Bhd.

Rejabhad. (1987). Tan Tin Tun. Siri Produksi Gila-Gila. Kuala Lumpur: Creative Enterprise Sdn. Bhd.

Rejabhad. (1988). Perwira Mat Gila. Kuala Lumpur: Creative Enterprise Sdn. Bhd.

Received: 27 April 2020

Accepted: 25 May 2020 